\title{
Identification of Bacteria on Seblak Food around University of Jember Based on Microbiological Criteria of Processed Food
}

\author{
Rizka Maulidya Cahyani ${ }^{1)}$, Joko Waluyo ${ }^{1)}$, Mochammad Iqbal ${ }^{1)}$ \\ ${ }^{1)}$ Biology Education, Faculty of Teacher Training and Education, University of Jember \\ email: jokowaluyo.fkip@unej.ac.id
}

\begin{abstract}
The quality of food must always be maintained to avoid diseases or health problems. Healthy and safe food is an essential factor in public health. Seblak is a ready-to-eat Indonesian street food that has never been tested microbiologically. Seblak is made from raw crackers, which is soaked in hot water to have a chewy texture. This study aims to determine the bacterial content of seblak through the process of isolation and identification in the macroscopic, microscopic, and biochemical way. This study used five samples, which was repeated five times for each sample. Bacteria were isolated from the sample using spread plate techniques and observed by growing colonies on the plate. Each different colonies was observed microscopically through gram staining and endospore staining. Biochemical tests were also carried out to provide secondary data. The results of the study showed the genus of Bacillus sp. is dominating the sample.
\end{abstract}

Keywords: Bacteria, Food, Seblak.

\section{INTRODUCTION}

Food is the most necessary, valuable, and natural thing that human needs after oxygen. Proper food must be considered, especially when the body is unhealthy (Apriadji, 2007). According to Arisman (2009), to maintain a healthy body, it is necessary to have food requirements that must be not only nutritious but also in good quality and safe to consume. Safe and healthy foods are essential factors to improve the standard of public health. Food quality, according to its physical, chemical, and biological characteristics must always be maintained to avoid disease or health problems.

Food safety is already a global problem that receives significant attention in the determination of public health policies. The spread of foodborne diseases and incidents of food poisoning does not only occur in developing countries where sanitation and hygiene conditions are generally poor but also occur in developed countries (Kurniadi et al., 2013). The incidence of food-borne diseases in Indonesia is quite significant. It can be seen from highly infectious diseases such as typhus, cholera, dysentery, and so on. Approximately $90 \%$ of food poisoning cases are caused by microbial contamination (Hartono, 2006).

Djaafar and Rahayu (2007) say that food can carry a variety of microbes derived from natural microflora of plants or animals, both originating from the environment and those that enter during harvesting or slaughtering, distribution, post-harvest handling, processing, and even storing products when it is finished. Various types of microbes, especially pathogenic bacteria, can be found in almost all places. Soil, air, water, animals, plants, humans, foodstuffs, even in various objects, including equipment used in food processing, are typical habitat for bacteria.

A similar case happens to human intestine. Dirty food can carry bacteria to the intestine. If harmful bacteria thrive, the balance of microbes in the intestine will be disturbed (Widodo, 2002). According to Djaafar and Siti (2007), microbes can grow and develop in a short time and in conditions that support such as nutrients availability, $\mathrm{pH}$, and temperature. Pathogenic bacteria found in polluted foods can contaminate other foodstuffs, such as vegetables, fruits, and ready-to-eat foods. Therefore, food quality must be highly considered.

Food and beverages must go through the stages of quality and nutritional testing to guarantee safety. The food safety is carried out through sampling and testing of microbes (BPOM, 2016). Identification of microorganisms, especially bacteria, is essential for other fields of research and applied industries, for example, agriculture, clinical microbiology, and food production) (Bisen, et al., 2012: 275). 
Food microbiology studies the effect of bacteria on food, including the role of bacteria in food production, food destruction, food contamination, and poisoning. Many microbiological roles are utilized in food production, such as in bread, tempeh, and beer. On the other hand, microorganisms can also be detrimental to health (Amaliyah, 2017). According to Proto'u et al. (2015), several aerobic bacteria are suspected to be the cause of most cases of food poisoning, including Salmonella, Shigella, Escherichia coli, Vibrio cholera, and Staphylococcus aureus.

The identification of bacteria and its feasibility to health tests on seblak has never been made, so it's not yet known what types of bacteria are in this food. Therefore, it is necessary to determine the bacteria that may be pathogenic and potentially cause diseases, especially on the digestive tract. Seblak is a traditional Indonesian food from Bandung made from raw crackers soaked in hot water, so it has a chewy texture. Seblak is usually served with eggs or other additions according to one's taste (Febriyanti, 2018).

Several incidents happened regarding health issues and hygiene standards of the food street vendors or food factories. Police confiscated boxes of ready to cook ingredients and seasonings of seblak from a food factory in Karawang, West Java, due to BPOM permit distribution. Another case happened in Garut, West Java, where students from an Islamic boarding school rushed to the local health facility from seblak poisoning (Rihanto, 2018; Ghani, 2018). So, it is necessary to find out the organic poison that pollutes this famous street food.

This study is a descriptive exploratory study aimed to find out the bacteria in seblak. The study was carried out through the isolation stage, macroscopic identification, microscopic identification, and biochemical test.

\section{METHODS}

\section{a. Place and Time of the study}

The study was carried out in the Sub Laboratory Microbiology, Biology Education University of Jember. Samples were collected from the street vendors around the university from April to June 2019.

\section{b. Samples Preparation}

Seblak was collected from five vendors. Samples in airtight containers were brought to the laboratory to begin the examination. Three serial dilutions were prepared from the finely ground samples $\left(10^{-1}\right.$, $\left.10^{-2}, 10^{-3}\right)$. Each sample was inoculated five times in different petridishes. The medium used was Nutrient Agar.

\section{c. Bacteria Isolation}

As much as $0,1 \mathrm{ml}$ of each dilution were inoculated onto the petridisks using spread plate technique until the surface of petridish dried. Each bacterial culture was labeled according to the type of sample. Cultured bacteria were put in the incubator for 24 hours at $37^{\circ} \mathrm{C}$.

The amount of the growing colonies were marked and examined. The purification was then carried out using the same technique to separate individual colonies.

\section{d. Macroscopic and Microscopic Observation}

Bacterial cultures incubated for 24 hours at $37^{\circ} \mathrm{C}$ were observed macroscopically by observing the growth of the colony, including the overall and the edge shape of the colony, surface, color, and elevation. The parameters for microscopic observation were Gram staining and endospore staining. Colonies with different characteristics were labeled.

\section{e. Biochemical Test}

The biochemical tests carried out in this study include:

\section{Oxidase Test}

The test was to find out whether the bacteria can produce enzyme cytochrome oxidase. The test was done by scraping cultures using an inoculating needle loop on a filter paper dropped with tetramethyl-pphenylenediamine dihydrochloride reagent.

\section{Catalase Test}

This test was to determine the ability of bacteria to reduce hydrogen peroxide $\left(\mathrm{H}_{2} \mathrm{O}_{2}\right)$. It is done by taking each bacterial culture on an object glass and then dropping it with $\mathrm{H}_{2} \mathrm{O}_{2}$ using a pipette and mixing it with an inoculating needle loop. 
3. Indole Test

This test was to detect the ability of bacteria to degrade tryptophan. The test was done by planting each bacterial species on Nutrient Broth in a test tube. The inoculum was then reincubated at $37^{\circ} \mathrm{C}$ for 24 hours. After that, the Kovacs reagent was added, and the changes of medium were observed. This test can also be used to identify the type of bacteria based on their oxygen requirements.

\section{f. Data Analysis}

The obtained data were analyzed descriptively by observing the morphological characteristics, microscopic observation, and biochemical tests result.

\section{RESULT AND DISCUSSION}

The result showed that there were eight different bacterial isolates. However, after several inoculations, all isolates showed almost the same colony shape, which was a concentric circle. One difference showed by isolate \#4, which grew faster than the other isolates. Figure 1 showed the result of Gram staining.

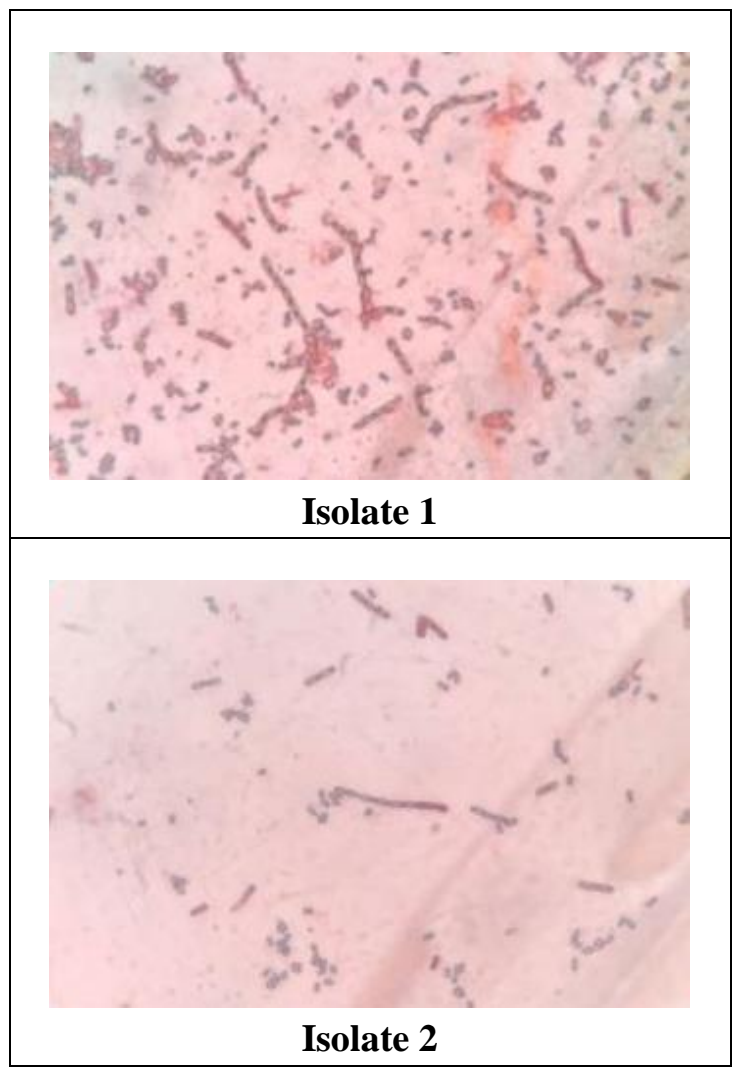

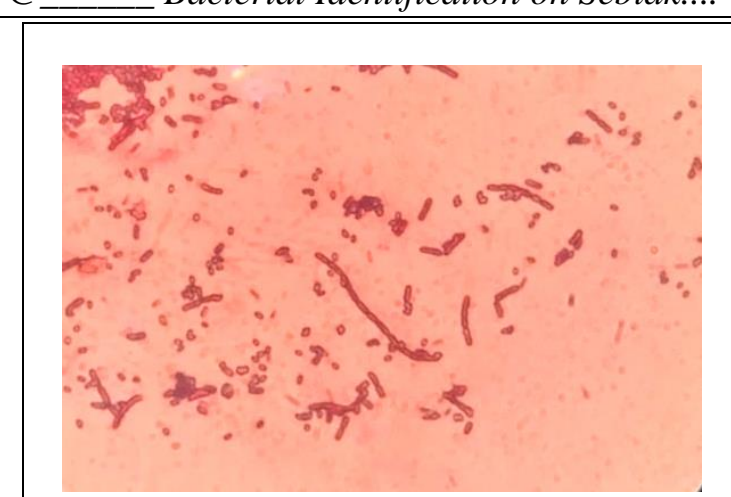

Isolate 3

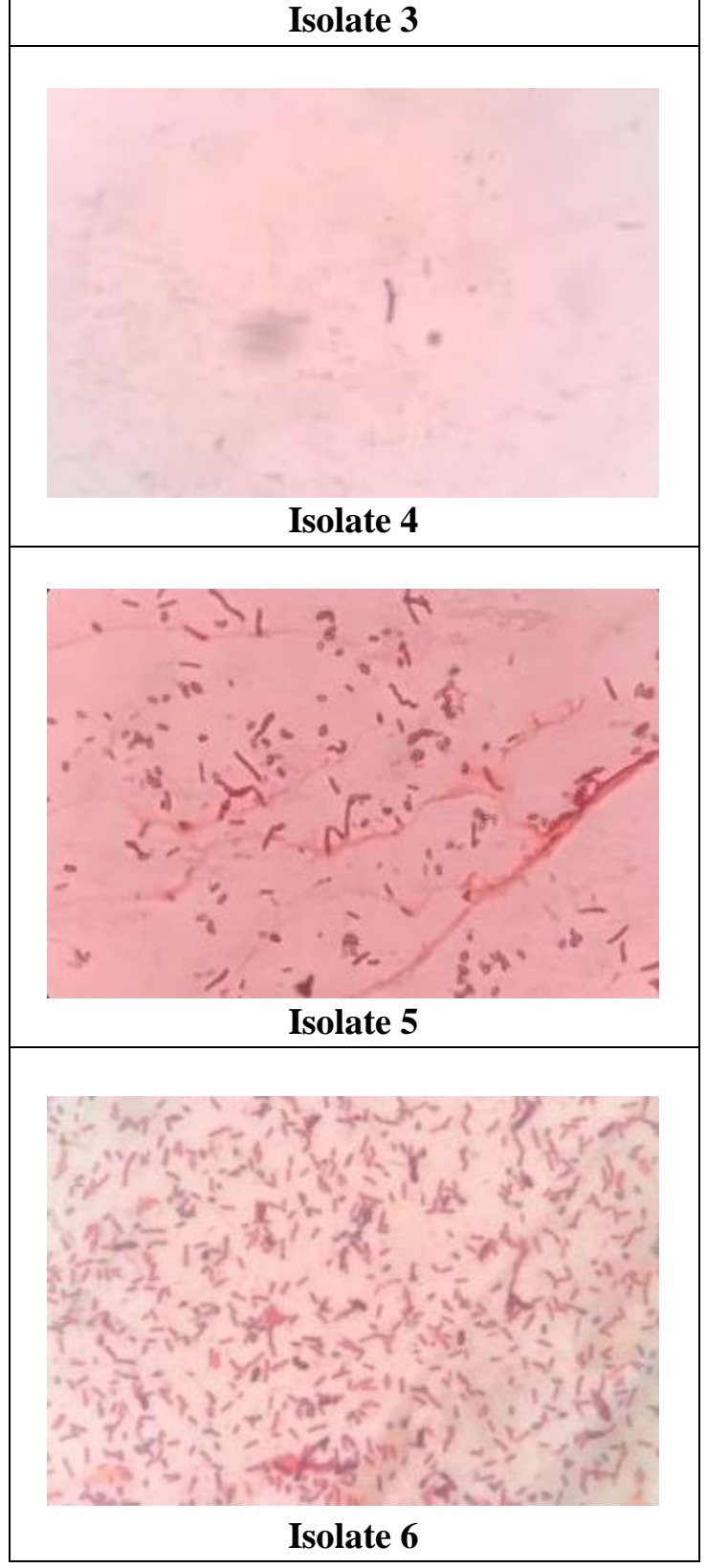




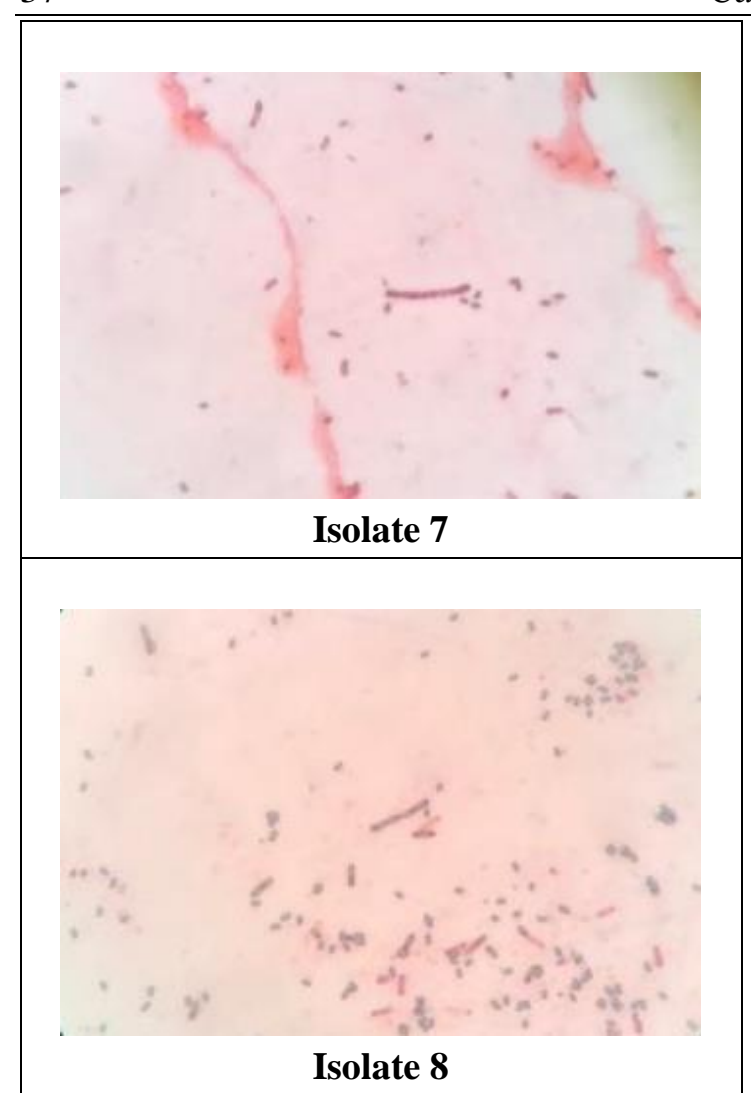

Figure 1. Gram-Stained cells

Identification was conducted to all isolate found. There were eight isolates found from all the samples, but several isolates have the same characteristics after further observation. From macroscopic observations, all isolates showed the same characteristics, whereas in microscopic observations, isolates $1,2,3,7$, and 8 had the same shape and isolates 4,5 , and 6 showed slightly different characteristics.

The macroscopic observation was conducted through two methods, which were gram staining and endospore staining. Based on gram staining, bacteria are divided into two groups depending on the reaction of the cell wall to the safranin or crystal violet dye. A gram-positive bacteria shows blue or purple color after stained with crystal violet dye.

On the other hand, Gram-negative bacteria colors in pink, because it retains safranin dye on its wall (James et al., 2008).

Bacterial endospores are difficult to observe using the gram staining method. The cells need to be warmed up to color the endospores so that the green malachite paint can enter the spores. Safranin $0.5 \%$ is also needed, in addition to green malachite, to clarify the observation of vegetative cells and is easily distinguished. Thus, these cells will be red, while endospores will be green.

Biochemical characteristics are essential criteria in the identification of bacterial specimens. Bacteria can't be solely recognized by their morphological features, because different cells may look the same. Microbes can grow in several types of media and produce metabolites that can be detected by various reagent test solutions (Murray, 2015).

Biochemical tests conducted in this research were the oxidase test, catalase test, and indole test. The oxidase test is used to detect the cytochrome oxidase enzyme, which catalyzes the transport of electrons between cells in bacteria to reduce oxygen at the end of the electron transport chain. A colorless redox reagent, tetramethyl-p-phenylenediamine dihydrochloride, can be used to detect the presence of oxidase enzymes. If it reacts with oxygen, it will change the color (LibreTexts, 2019). There are many methods for this test. One of them is filter paper. If the paper turned blue, it indicates that the oxidase is positive. Whereas, if it did not change color, it means that the bacterium was a negative oxidase (Aryal, 2018; Dalynn, 2014).

Bacteria have a way to maintain each life. Reiner (2010) explained that organisms must rely on defense mechanisms to survive, which allow them to repair or avoid oxidative damage to hydrogen peroxide $\left(\mathrm{H}_{2} \mathrm{O}_{2}\right)$. Catalase neutralizes the damaging effects of hydrogen peroxide (Wheelis, 2008). During respiration, microorganisms, whether its aerobes, facultative anaerobes, and microaerophiles, produce the toxic $\mathrm{H}_{2} \mathrm{O}_{2}$ (Cappucino and Sherman, 1992:171). The catalase test was observed with the formation of bubbles after the dropping of the hydrogen peroxide $\left(\mathrm{H}_{2} \mathrm{O}_{2}\right)$ solution.

An indole test is conducted to find out the ability of bacteria in the enzymatic degradation of tryptophan amino acids. Tryptophan is a component of amino acids commonly found in proteins. Thus, this amino acid is easily used by microorganisms due to protein breakdown (Volk and Wheeler, 1993). Control bacteria which are often used for this test are Escherichia coli for positive control and Proteus mirabilis as a negative control (Public Health England, 2014). The indicator of the indole test was the formation of a red ring on the surface of the liquid medium, which means the positive indole test. 
From the microscopic observation, isolate $1,2,3,4,7$, and 8 had the same character. They were Gram-negative streptococcus. Isolates 5 and 6 were also Gramnegative but in the form of bacilli. Colonies of all isolates after several inoculations showed the same characteristics, which were forming concentric circles, but isolate 4 showed a faster growth rate than other isolates. Endospore staining also showed that all isolates were found to have endospores. Thus, according to the identification key of V. B. D. Skerman (1949), rod-shaped and Gram-negative bacteria had spores included in the genus Bacillus.

Cultures in Nutrient broth showed that all isolate was obligate aerobic bacteria, except isolate 4, which was anaerobic-facultative bacteria. According to Public Health England (2018), the genus Bacillus could be aerobic or facultative-anaerobic, and most species are motile (except Bacillus anthracis). Bacillus was the group that had the most significant number of species and is easily found. PHE (2018) data showed that currently, the genus Bacillus has 268 species and 7 subspecies, although some had been included in other genera.

Genus Bacillus is commonly found in the environment and often become contaminants in the laboratory. Some Bacillus species have also been known to cause infection in humans (Euzéby, 1997; Koneman et al., 1997). This genus has varied grams, often arranged in pairs or chains with rounded or square ends, and usually has a single endospore very resistant to adverse conditions that help it to survive (Public Health England, 2018).

Endospores allow bacteria to survive in extreme conditions that usually kill bacteria. Cornell CALS (2019) explains that when the nutrients needed by bacteria are used up, some bacteria may become motile to look for these nutrients. Meanwhile, other bacteria produce specific enzymes. One example is the Grampositive $\mathrm{G}+\mathrm{C}$ bacteria forming endospores. The formation of endospores will begin in response to a lack of nutrients. In this harsh condition, bacteria produce an active and resistant part to maintain their genetic material in the form of an endospore. It explains the ability of Bacillus to grow in vast numbers and are almost found in all sample plates.

The biochemical test showed different results. All isolates tested positive either for catalase and oxidase, except for isolate \#3 (positive for catalase) and isolate \#2 and \#8 (positive for oxidase). Public Health England (2018) stated that most oxidase species were positive, which could cause errors with Pseudomonas. Bacillus usually shows positive catalase and metabolizes carbohydrates by fermentation. $B$. anthracis is almost always sensitive to penicillin, while other species were generally resistant.

Disease caused by Bacillus is rarely reported because most of the symptoms are relatively mild and only of short duration. Diarrhea is often caused by foods containing meat, vegetables, sauces, and dairy products (De Blackburn and McClure, 2009: 852). Spore-forming bacteria such as $C$. botulinum and $B$. cereus cause food poisoning because they reduce the nutritional value, function, and quality of food (Hauschild, 1990; Lindbäck and Granum, 2006). The best-known genus of Bacillus as a foodborne illness is B. cereus (De Blackburn and McClure, 2009; Public Health England, 2018). According to the Food and Drug Supervisory Agency (2006), species of Bacillus cereus bacteria found in starch and starch-based foods may be present in foods with a bacterial content limit of $10^{3}$ colonies/gram.

\section{CONCLUSION}

All the samples of seblak obtained from street vendors around Jember University contain Bacillus sp.

\section{REFERENCES}

Amaliyah, N. 2017. Penyehatan Makanan dan Minuman. Yogyakarta: Deepublish

Apriadji, W. H. 2007. Good Mood Food: Makanan Sehat Alami. Jakarta: Gramedia Pustaka Utama

Arisman. 2009. Keracunan Makanan. Jakarta: Penerbit Buku Kedokteran, EGC

Aryal, S. 2018. Oxidase Test - Principle, Uses, Procedure, Types, Result Interpretation, Examples and Limitations. https://microbio logyinfo.com/oxidasetest-principle-uses-procedure-typesresult-interpretation-examples-andlimitations/. [Diakses pada 25 Juni 2019] 
Atlas, R. M. 1946. Handbook of Microbiological Media for the Examination of Food. NW: CRC Press

Badan Pengawas Obat and Makanan. 2016. Kriteria Mikrobiologi dalam Pangan Olahan. Kepala Badan Pengawas Obat dan Makanan Republik Indonesia

Bisen, P. S., M. Debnath and G. B. K. Prasad. 2016. Identification and Classification of Microbes. USA: Wiley-Blackwell

Cappucino, J. G. and N. Sherman. 1992. Microbiology a Laboratory Manual. USA: The Benjamin/Cummings Publishing

Cornell CALS. 2019. Bacterial Endospores. https://micro.cornell.edu/research/epulo piscium/bacterial-endospores/s [Diakses pada 25 Juni 2019]

Dalynn Biologicals. 2014. Oxidase Reagent. Catalogue No. RO95. Canada

De Blackburn, C. W. and P. J. McClure. 2009. Foodborne pathogens. US: Woodhead Publishing

Djaafar, T. F. and S. Rahayu. 2007. Cemaran Mikroba pada Produk Pertanian, Penyakit yang Ditimbulkan dan Pencegahannya. Jurnal Litbang Pertanian. Vol 26 (2)

Euzéby, J.P. 1997. List of Bacterial Names with Standing in Nomenclature. International Journal of Systematic Bacteriology. Vol 47: 590-592

Ghani, H. 2018. Puluhan Santri di Garut Keracunan Diduga Usai Santap Seblak. https://news. detik.com/berita-jawabarat/d-4305702/pu luhan-santridi-garut-keracunan-diduga-us aisantap-seblak. [Diakses pada 4 Juni 2018]

Hartono. 2006. Penyakit Bawaan Makanan: Fokus Pendidikan Kesehatan. Jakarta: Penerbit Buku Kedokteran, EGC
Hauschild, A. H. W. 1990. Clostridium botulinum toxins. Int. Journal of Food Microbiol. Vol 10: 113-24

Himedia. 2003. Technical Data for Nutrient Agar. Mumbai: HiMedia Laboratories Pvt.

James, J., C. Baker and H. Swain. 2008. Prinsip-Prinsip Sains Untuk Keperawatan. Jakarta: Penerbit Erlangga

Koneman E. W., Allen S. D., Janda W. M., Schreckenberger P. C. and Winn W. J. 1997. Color Atlas and Textbook of Diagnostic Microbiology. 5th ed. Philadelphia: Lippincott Williams and Wilkins

Kurniadi, Y., Z. Saam and D. Afandi. 2013. Faktor kontaminasi bakteri E. coli pada makanan jajanan dilingkungan kantin sekolah dasar wilayah Kecamatan Bangkinang. Jurnal Ilmu Lingkungan. Vol 7 (1): 28-37

Lehninger. 1995. Microbiology: A Laboratory Manual. California: Addison-Wesley

LibreTexts. 2019. 27: Oxidase Test. https://bio. libretexts.org/Ancillary Materials/Lab oratory_Experiments/Microbiology_Lab s I/27\%3A Oxidase Test. [Diakses pada 27 Juni 2019]

Murray. 2005. Buku Ajar Mikrobiologi. Jakarta: Penerbit Buku Kedokteran EGC

Proto'u, A. Ch., V. Buntuan and F. Rares. 2015. Identifikasi Bakteri Aerob pada Makanan Jajanan Jagung Bakar di Pinggiran Jalan Ring Road Manado. Jurnal e-Biomedik (eBm). Vol 3 (1)

Public Health England. 2018. Identification of Bacillus Species. London: UK Standards for Microbiology Investigations

Rahayu, E. S. 2006. Amankah produk pangan kita: Bebaskan dari cemaran berbahaya. Makalah disampaikan dalam Apresiasi Peningkatan Mutu Hasil Olahan Pertanian. Dinas Pertanian Provinsi DIY dan Kelompok Pemerhati Keamanan 
Mikrobiologi Produk Pangan.

Yogyakarta, 1 April 2006

Reiner, K. 2010. Catalase Test Protocol. US: American Society for Microbiology

Rihanto, D. 2018. Bahaya untuk Kesehatan, Bahan Baku dan Bumbu Seblak di Karawang Disita Polisi. https://www.pikiran-rakyat.com/jawa -barat/2018/11/30/bahaya-untukkesehatan-bahan-baku-dan-bumbuseblak-di-karawa ng-disita-polisi. [Diakses pada 20 Januari 2019]

Skerman, V. B. D. 1949. A Mechanical Key for The Generic Identification of Bacteria. Bacteriol Rev. Vol 13 (3): 175-188

Volk and Wheeler. 1993. Analisis Praktikum Mikrobiologi Umum untuk Perguruan Tinggi. Yogyakarta: UGM Press

Waluyo, J., D. Wahyuni and M. Iqbal. 2017. Modul Praktikum Mikrobiologi. Jember: Universitas Jember

Wheelis, M. 2008. Principles of modern microbiology. Massachusetts: Jones \& Bartlett Publishers. Inc.

Widodo, W. 2002. Bioteknologi Fermentasi Susu. Pusat Pengembangan Bioteknologi: Universitas Muhammadiyah Malang 